\title{
Study on Perception and Acceptance of Nutmeg Farmers Toward the National Rehabilitation Program: Increasing the Production of Cash Crop Commodities (Nutmeg) in Tidore-North Maluku-Indonesia
}

\author{
Mardiyani Sidayat ${ }^{1, *}$, Mila Fatmawati ${ }^{1}$ \\ ${ }^{I}$ Dept. of Agribusiness, Faculty of Agriculture, Universitas Khairun, Ternate, Indonesia \\ "Corresponding author. Email: dhiany_220973@yahoo.com
}

\begin{abstract}
The majority of farmers in North Maluku are planting cash crops such as coconut, nutmeg and clove as their main source of income. In the study sites (Kota Tidore region) Most of the farmer have cash crop as the major agricultural commodities. The central government introduced a national program of increasing the cash crop commodities production (nutmeg) in 2017, which aimed to help the sustainable development of cash crop (nutmeg and clove) productions in supporting the farmer's income. Through this program the government distributed seeds, organic fertilizers and tool (hoe) as well as accompanying the farmers in the first phase of the program. This study purpose to identify the nutmeg farmer's perception and acceptance toward the assistance received from the government. It also can help to ensure that the program is contributing to the benefit of the farmer as well as can be taken as a lesson learned for the future program. The research is conducted in three villages, Rum, Maftutu and Kalaodi in Tidore regency which has received this program in 2017. The result shows that the perception of farmer toward the kind of assistance (seeds and organic fertilizers) are at the very satisfy level based on the reason that the quality of seeds is adequate to use (selected from the best local seeds) and organic fertilizers is not harm the soil. Similarly, the quantity of the distributed items is enough to be used by the farmers. While, they did not satisfy for tools (hoe) because of the number received is less than the number of beneficiaries. In the side, the acceptance level of the nutmeg farmers toward the kind of assistance (seeds, organic fertilizer and hoe are at the high level category because of those items distributed are well accepted and able to suit their basic needs on the ground. for items not enough for all the members (hoe), they literally manage it collectively.
\end{abstract}

Keywords: nutmeg, perception, acceptance

\section{INTRODUCTION}

The global demands of the cash crops are increased gradually. Cash crops are main agricultural commodities have great contributions to the Indonesian national Income. The central government initiate to increase the productivity of cash crops through the use of superior seeds, and implementing other rehabilitation programs [1]. In North Maluku context, the majority of the farmers are planted cash crops such as, clove, coconut and nutmeg as their main source of income. It is mostly applied in smallholder cash cropping and often without using modern tools and fertilizers. Likewise, in Tidore island region, the nutmeg farming areas is about $3.290,55 \mathrm{Ha}$ with total production of $830,6 \mathrm{Ha}$ /Ton with productivity rate is about 46,2 and the number of a farmer working in this field is 8745 farmers [2].
Culturally, the local farmers have already planted this crop in intra generations and having their local knowledge in managing this plant. They also consider that nutmeg is easy to plant, no need many maintenance activities, and having a stable price in the market, so somehow it is prospective for their own income. In 2007, the agriculture ministry is implemented the national program which aims to increase the cash crops (including nutmeg) production in supporting the farmer's income. This program is consisting of rehabilitation effort and cash crop expansion [3]. Through this program, the government distributed nutmeg seeds, organic fertilizers and tool (hoe) as well as accompanying the farmers for technical assistance in the first phase of the program.

In order to find out the nutmeg farmer perception and acceptance toward the program, the study is conducting in three locations of the project in Tidore island regions. In addition, this study also can be a tool to measure and ensure that the program is carry out properly and able to 
contributing for nutmeg sustainable development which also will be very beneficial to be used by the government in improving their quality of the program in the future.

\section{METHODS}

The study has taken place in three project locations in Tidore Island region which are Rum, Maftutu, and Kalaodi villages. Sampling chosen is using a purposive sampling method, which refer only to the nutmeg farmers who receive the assistance.

This research is descriptive qualitative, where the data taken is from field observation and direct interview with farmers who received assistances. Data on perception and level of acceptance is taken base on the criteria set out on the questionnaires which are then tabulated base on observation rate divide with expectation rate per respondent and then percentage it. The level of perception is categorized into very satisfy $(80-100 \%)$, satisfy (59$79 \%$ )and not satisfy $(0-58 \%)$. Whilst, the level of acceptance is dividing into, high (80-100\%), moderate (59$79 \%)$ and low $(0-58 \%)$.

In order to classify the level of perception and their acceptance, the questions have set out which consisting of nine points (kind of item distributed, selection for receiving assistance, dissemination of information on how items distributing to the farmer, quality of distribution management, quality of item distributed, quantity of item distributed, the role of field staff-from Agriculture department, controlling \& monitoring and accompaniment.

Later, from the observation and expectation rate calculated, we analyse further using the Pearson Product Moment test to see the correlation of the perception and acceptance of the farmers.

\section{RESULTS AND DISCUSSION}

\section{A. Respondent Profile}

The total numbers of respondents are 25 farmers and all of them were male-headed households. Respondent age classification was ranging between $25-55$ year old $(76 \%)$ dominate and followed by $>55$ years old $(24 \%)$. Majority of them having completely junior high school (44\%), $36 \%$ completed senior high school and the rest $(20 \%)$ only completed primary school. All of them owned the nutmeg farming land with the size of land were between 1-2 hectares $(56 \%),<0,5-1$ hectares are about $24 \%$ and the rest $20 \%$ are having land $>2$ hectares.

\section{B. Farmer's Perception toward the kind of assistances received}

The rate of farmer's perception toward the seeds and organic fertilizer assistances are about $62.96 \%$ and/or at the satisfy level. While, for the tool (hoes), the level of satisfaction is at the not satisfy level $(55.55 \%)$. Majority of respondents stated that the assistance is very useful because it suits their need on the ground. Similarly, the quality and quantity of seeds and organic fertilizers received are adequate to apply and distribute it among them, even they also can share it with other nutmeg farmers who are not beneficiaries but intend to plant it in their own farm. However, they have a remark on the ways of item distribution, where the packaging of seeds distributed are not handling properly as well as the information regarding the distribution time is unclear, so the preparation of receiving the items by the farmer are not well managed. By contrast, they a little bit disagree with the tools, where the implementer only distributing hoes without other essential tools such as machete and grass rake.

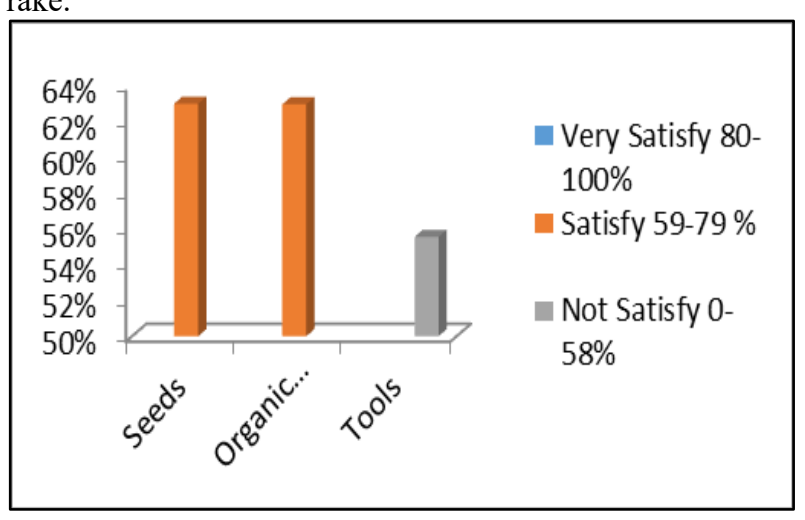

Figure 1. Farmer's Perception

\section{Farmer's Acceptance toward the kind of assistance received}

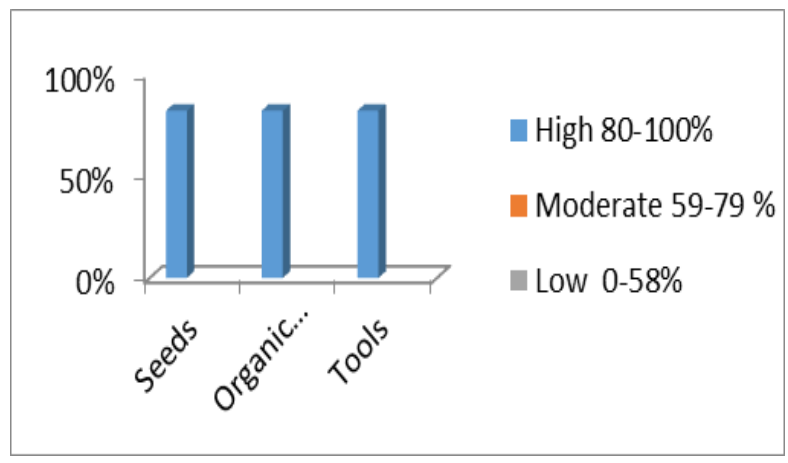

Figure 2. Farmer's Acceptance

The level of farmer's acceptance toward the program are at the high level $(82 \%)$ as they considering that the kind of assistance is accordance to their basic needs, though still there are mistaken found out, such as the number of hoes are less than the beneficiaries, but in the practical they are able to manage it collectively. The farmers are also well accepted the program because of cash crop are seems to be part of their life as they culturally planted it since a long time ago and still recognizing themselves as cash crop farmer rather than other horticulture crops.

\section{Pearson Product Moment Test}

Pearson Product Moment)

$$
\mathrm{r}=\frac{\mathrm{n} \Sigma \mathrm{xy}-(\Sigma \mathrm{x})(\Sigma \mathrm{y})}{\sqrt{ }\left\{\mathrm{n} \Sigma \mathrm{x}^{2}-(\Sigma \mathrm{x})^{2}\right\}\left\{\mathrm{n} \Sigma \mathrm{y}^{2}-(\Sigma \mathrm{y})^{2}\right\}}
$$




$$
\begin{aligned}
& r=\frac{257206-(424)(424)}{\sqrt{ }\left\{25848^{2}-(179.776)\right\}\{25848-(179.776)\}} \\
& r=\frac{180.150-179.776}{\sqrt{\{-153928)\}\{25848-(-153928)\}}} \\
& r=\frac{374}{\sqrt{\{-153928)\}(-153928)\}}} \\
& r=\frac{374}{\sqrt{23693829184}} \\
& r=\frac{374}{153.928} \\
& r=2.429707
\end{aligned}
$$

The correlation between the perception and the acceptance of the farmers toward the program is positive which means if the farmer more satisfy to the program then the level of acceptance also increase.

\section{E. Factors supporting the farmer's perception and acceptance toward the program}

\section{Type of the Program}

According to the respondent, the rehabilitation program to increase the cash crop production is a very beneficial program due to the fact that the cash crops (nutmeg) face many challenges, particularly related to improving the productivity and quality of nutmeg cultivation. Similarly, they stated that the quality of item distributed (seeds, organic fertilizers and tools ) are qualified to use. For instance, the quality of seeds is taken from superior local seeds (certified nutmeg seeds) called Ternate 1 and Takome 1 which empirically proven can grow and well survive in their own farming. The farmers also have own knowledge in recognizing the quality of seeds base on their empirical experiences and agree that the seeds are the superior ones. Compare to the previous assistances, where the seeds are not well selective, so it useless to be used by the farmers. Perception of people can be formed by needs and past experience [5]. It well understood, if the farmer's perception and acceptance to the program is quite impressed.

Similarly, for the organic fertilizers, as they never use it for nutmeg but in practical, it commonly uses for other vegetable crops. In their perception, better for trying organic fertilizers as it only has biodegradable content and more friendly to the environment. Awareness on using organic fertilizers is well understood by the majority of the respondents. Quantity of items distributed (seeds and organic fertilizers) are sufficient enough to distribute among the members and even it also can share with other nutmeg farmers who are not receiving the assistances. By contrast, for the number of tools (hoe) received are less than the number of beneficiaries, but somehow, they decided to keep it as the collective properties and able to be used revolved by all the members. Commonly, Farmer is motivated to participate on a particular development program as stimulated by gaining more benefit rather than risk. Participation is predicted to continue as long as a farmer are satisfied and/or benefitted from those activities [6].

\section{The role of extension agents from agriculture office}

A role can be seen as a as a set of norms, values and interaction patterns [7]. It somehow can affect the socialrelationship inter people who interact each other, particularly in regular basis. The extension agents who work in those villages are working for almost over than five years and knows well the farmers socio-cultural background. They plays important role in educating farmers by motivating them to learn and to adopt new technology. The effectiveness of the extension agent can often determine the success or failure on an extension programs [8]. Likewise, for this program, the extension agents accompany and provide technical assistances for the planting process as well as its maintenance. It also found out that the farmers are able to discuss and to argue openly with the extension agents towards the program.

\section{Existence of Communal-based system}

The people in the study sites are the small community, smallholder farmers, who share the cultural values of living together as well as a similar belief and common behavior. It somehow helps them to manage the resources equitably and also in setting up common arrangements to overcome the disputes among them. For instance, the tools (hoes) are less than the number of beneficiaries, but then, they decide to use it collectively by saving them as the communal property. Every member can use it and return them back after work, and it is proven that all of them agree and followed the collective decision made. Communal-based systems are requiring people to work together for a collective goal and to cooperate [9]. It can be seen that cultural homogeneity is proven to facilitate their heterogeneity and contributes to rebuild their social cohesion and enhance their solidarity [10]. In addition, nutmeg cultivation in the study sites are guided by the custom, which mostly prioritizes the communal rights that allow all the members can gain the same benefit.

\section{CONCLUSION}

The perception and acceptance of the farmers toward the national rehabilitation program to increase the cash crop (nutmeg) production are supported by three factors; 1) the type of program which can suit the needs of farmers on the ground because of providing qualified items of assistances (seeds, organic fertilizers); 2) The role of extension agents from agriculture office; 3) Existence of communal-based system. As fully understood is the perception and acceptance is interrelated each other, when the farmer satisfy with the program content and the acceptance toward the program also increase 


\section{ACKNOWLEDGMENT}

The author would like to thank to LPPM Universitas Khairun for the research fund to the 5th FANRES International conference 2019 committee for holding a seminar at Universitas Khairun.

\section{REFERENCES}

[1] Rencana Strategis Kementrian Pertanian Indonesia.2015-2019 (2015).

[2] Statistic Data. Kota Tidore Dalam Angka. 2017

[3] Dirjen Prasarana Kementerian pertanian. 2015. Pedoman Teknis Pengembangan Optimasi Lahan APBN-P. Direktorat Perluasan dan Pengelolaan Lahan Direktorat Jendral Prasarana dan Sarana Pertanian Kementrian Pertanian. Jakarta. Indonesia

[4] Sidayat Mardiyani. Community-based fishery management in the post conflict situation. A case study in coastal villages-North Maluku-Indonesia. Journal of Rural Indonesia (JORI).2017

[5] Krech and Crutchfield. 1948 in Meyliani R. Persepsi mahasiswa baru terhadap citra fakultas pertanian UGM Yogjakarta. Universitas Gajah mada 2015. In Aulifia et al. Persepsi anggota grup facebook' Komunitas Hidroponik Jogja(HI-)JO terhadap pengembangan hidroponik. Journal Agro Ekonomi. Vol 27.No 2 Desember 2016, UGM Jogjakarta.

[6] Irawan, E. prospek Partisipasi Petani dalam Program Pembangunan hutan rakyat Untuk mitigasi perubahan iklim di Wonosobo. Journal Ekonomi Pembangunan 12 (1) 67-76

[7] Anaeto F.C., Asiabaka C.C., Nnadi F.N, Ajaero J.O, Aja O.O,Ugwoke F.O, Ukpongson M.U1, Onweagba A.E (2012). The role of extension officers and extension services in the development ofagriculture in Nigeria. Wudpecker Journal of Agricultural Research Vol. 1(6), 180 - 185.

[8] Oakley, P. and Garforth, C. (1985). Guide to Extension Training.Rome: Food and Agricultural Organization of the United Nations in Jasmin Arif Shah et al. Roles of Extension Agents Towards Agricultural Practice in Malaysia.International Journal on advance science engineering information technology. Vol.3 (2013) No. 1 ISSN: 2088-5334

[9] Kean.M.A, M. (1996) 'Common property regimes as a solution to problem of scale and Linkage', in Right to Nature: ecological, economic, cultural and political principles of institution for environment (pp. 223-242). Stockholm Sweden: The Beijer International Institute of Ecological Economic.

[10] Sidayat Mardiyani. Community-based fishery management in the post conflict situation. A case study in coastal villages-North MalukuIndonesia.Journal of Rural Indonesia (JORI).2017. 